\title{
クモの糸の秘密
}

\section{Mystery of Spider Silks}

大 㠃茂 芳

\section{1. はじめに}

20 世紀の後半は、人類の創り出すハイテクノロジーが すべてであるかのような錯覚を与えた時代であった。とこ ろが、“スマトラ沖”大地震や米国の “カトリーナ”によ る大水害などのようにいくらハイテク時代といえども太刀 打ちできない場合がある。このことから、人類といえども、 やはり長い進化の歴史を持つ生物に学ばねばならないこと が分かり、「自然に学べ」というキーワードが生きてくる。 ここで取り上げるクモも長い期間に厳しい自然環境の下で 糸という道具を巧く使いながら生き延びてきた。そのクモ に焦点を当ててみると、クモの巣の張り方の神秘性や、そ の強さに驚いたりする。実際、糸の強さや柔軟性はどのよ うになっているのであろうか? 細い命綱を通じてどのよう な危機管理をして生きのびてきたのであろうか？また、命 綱のどこを信頼しているのであろうか？などいろいろな疑 問が湧いてくる。もしかしたら、クモの糸には何か秘めら れたものがあるのではないのか？と思ってしまう。そこで、 その秘密の一端を哯いてみたい。

\section{2. クモの巣と糸の性質}

\section{1 クモの巣の構造}

クモは世界中に約 4 万種いる中で、日本には 1200 種ほ どいる。その約半数は巣を張る造網性のクモであり、残り は巣を張らない非造網性のクモである。すべてのクモは糸 を出すことでは共通している11。

クモの腹部にある多数の吐糸管はいろいろな形の絹糸腺 に連結している。腹にある七個の絹糸腺は、大霊状腺(だ いのうじょうせん)、小囊状腺、管状腺、聚状腺(じゅじょ うせん)、鞭毛状腺(べんもうじょうせん)、葡萄状腺(ぶど うじょうせん)、梨状腺と呼ばれる。7 種類の絹糸腺から はそれぞれ異なったアミノ酸組成を持つタンパク質が分泌 され、それぞれの目的に合った機能を果たしている。

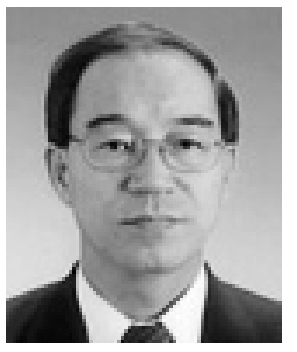

\section{SHIGEYOSHI OSAKI}

奈良県立医科大学 医学部 教授 理学

博士 (大阪大学)、農学博士 (京都大学)

下634-8521 奈良県橿原市四条町 840

Tel : 0744-22-3051 Fax : 0744-29-8810

E-mail : s-osaki@naramed-u.ac.jp

〈専門〉生体高分子学

〈趣味〉絵を描くこと、旅行
巣を張るクモの中でよく見られる円網は種々の糸から構 成されている(図1)。巣の中心部は糸をやや密に張った「こ

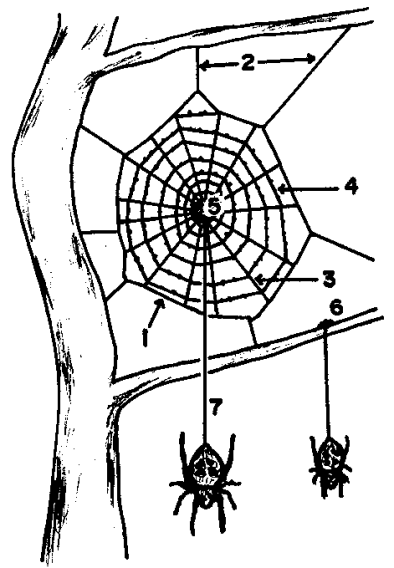

図 1 クモの円網の構造

1. 枠系, 2. けい留系, 3. 縦系, 4. 横系,

5.こしき，6. 付着盤，7. 率引系

しき」というクモの住居になっている。巣の中心部から外 へ放射状に伸びている糸は、巣の骨格を形成する「縦系」 といわれ、力学的に強い。粘着球がほぼ等間隔につき、渦 巻き状に張られている「横糸」は、弾性的で非常に伸びや すく、獲物捕獲に適した機能を持っている11。また、巣を 囲んでいる「枠糸」や、枠系と木をつなぐ「けい留糸」が ある。「牽引糸」はクモが獲物を迅速に捕まえる際や危機 に遭遇した場合などの命綱としての役割を果たしている。 卵を保護するための「卵のう」の表面は、規則的に編まれ た織布とは違って、太い糸と細い糸からなる繊維が不織布 状になっている。

\section{2 毫引糸の物理化学的性質}

ジョロウグモ旁引系はグリシン、アラニン、グルタミン 酸の三つの代表的なアミノ酸残基の繰り返しからなるタン パク質である2)。そして、旁引糸は春から夏にかけて白色 で、秋になると黄金色を示す。その密度は 6 月で $1.13 \mathrm{~g} / \mathrm{cm}^{3} 、$ 10 月で $1.29 \mathrm{~g} / \mathrm{cm}^{3}$ である ${ }^{3)}$ 。クモの体内の液状タンパク質 の分子量は約 27 万であり、分子量分布は非常にシャープ である4)。

ジョロウグモ旁引系は赤外線吸収スペクトルにおけるア ミド基の吸収バンド $\left(1510 \mathrm{~cm}^{-1}, 1630 \mathrm{~cm}^{-1}, 3200 \mathrm{~cm}^{-1}\right) に お$ ける顕著な二色性から纎維方向への配向性が見られる5)。 
その配向性はマイクロ波方式からも裏づけされる ${ }^{6)}$ 。非晶 性の牵引糸には明瞭な X 線回折パターンは得られていな いが、逆並行からなる $\beta$ 構造をとっていることが示唆さ れる7)。このように、牽引糸は非晶性のためか、融点がな く、少なくとも $200^{\circ} \mathrm{C}$ まで熱的に安定している2。

クモの糸は水で膨潤すると、長さが半分に収縮し、体積 は 2 倍になり、弾性は 1000 倍に増大する性質がある。こ の収縮力は、 $85 \%$ は高分子鎖の立体配置エントロピー変 化によるもので、それに対応したゴム成分の占める割合は 糸の 60〜 70\% を占めると推定されている ${ }^{8)}$ 。

\section{3 牽引糸の弾性率}

古くから強いといわれるクモの糸の弾性率は報告されて いるが9,10)、サンプルの断面積の求め方やどの時期のサン プルなのかははっきりしていない。そこで、測定するサン プルの断面積を電子顕微鏡から求め、ジョロウグモの若い 頃から成熟時までの牽引糸での弾性率を測定してみた。そ の結果、ジョロウグモの毫引糸の弾性率はクモの成長過程

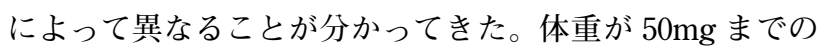
幼体での弾性率では $10.0 \mathrm{GPa}$ であるが、体重が $50 \mathrm{mg}$ 以上

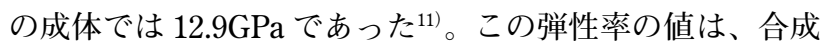
高分子の結晶領域の弾性率と比較すれば明らかに低いが、 非晶性高分子のポリスチレンの $1 \mathrm{GPa}$ 程度 ${ }^{12)}$ と比較すると かなり高い。つまり、通常の結晶性高分子の力学強度は非 晶域によって弾性率が規定されることから、クモの牽引糸 は非晶性高分子としては高い弾性率を持つことがわかる。

\section{3. クモから学ぶ危機管理}

\section{1 二本のフィラメントからなる命綱の強さはクモの重さ の約 2 倍 !}

クモの重さを支えている牽引糸は非常に細い糸であるに もかかわらず、クモがぶら下がっても切れず、空中で生活 しているクモの生死を左右するという重要な役割を担って いる。そのため、牽引糸は命綱といわれる。クモの重さを 支えている毫引系は、目視では一本に見える(図 2)。しか し、牽引糸を電子顕微鏡で観察してみると、円柱状の細い 二本のフィラメントからなっていることが判る(図 3)。

ジョロウグモ毫引糸の張力一伸び曲線を図 4 に示した。 張力に比例して伸びる限界点を弾性限界点といい、限界点 での張力を弾性限界強度、伸びを弾性限界伸びという。限 界点を越えると伸びは張力に比例しなくなる。弾性限界点 内の領域のことを線形領域といい、弾性限界点を超えた領 域のことを非線形領域という。弾性限界強度をクモの体重 に対してプロットしたところ、弾性限界強度はクモの体重

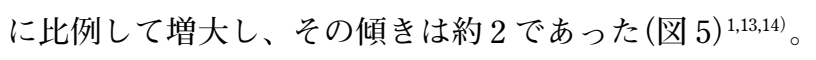
牽引糸の弾性限界強度は、いつも体重の約 2 倍に相当する のである。このことは、二本からなるフィラメントのうち、 たとえ一本のフィラメントが切れても、残りの一本のフィ ラメントでクモを支えることができることを意味している。 このように、率引糸は万が一の危機時に備えて、安全性の
観点から非常に効率的な命綱であることがわかる。

\section{2 “効率”と“ゆとり”を考えた安全性}

クモの巣づくりや獲物を捕える様子を眺めていると、巣 の芸術性やクモの巧妙さに驚いてしまう。そもそも、400 万年という人類の進化の歴史と比べて、クモは 4 億年とい う極めて長い進化の歴史を持っている。この気の遠くなる ような長い期間に、クモは環境に適応した機能を持つ糸を 作り上げてきたのであろう。長い進化の産物が、牽引糸の 弾性限界強度がクモの体重(ここでは重さ)の約 2 倍という ことである。言い換えれば、安全率 $(=$ 弾性限界強度／ク モの重さ)は約 2 ということになる11。

もし、弾性限界強度がクモの体重に等しいフィラメント 一本だけで支えられていると安全率は 1 で、エネルギー的

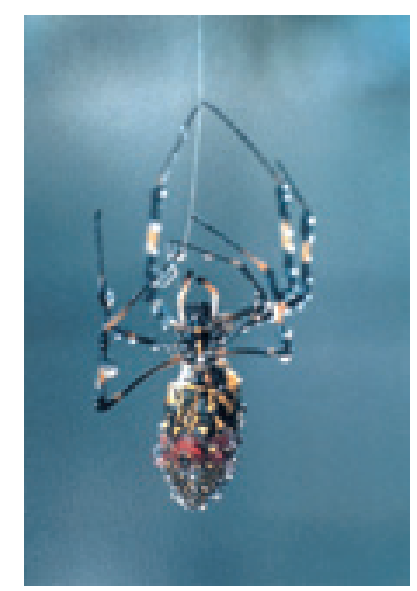

図 2 毫引糸にぶら下がるメスのジョロウグモ

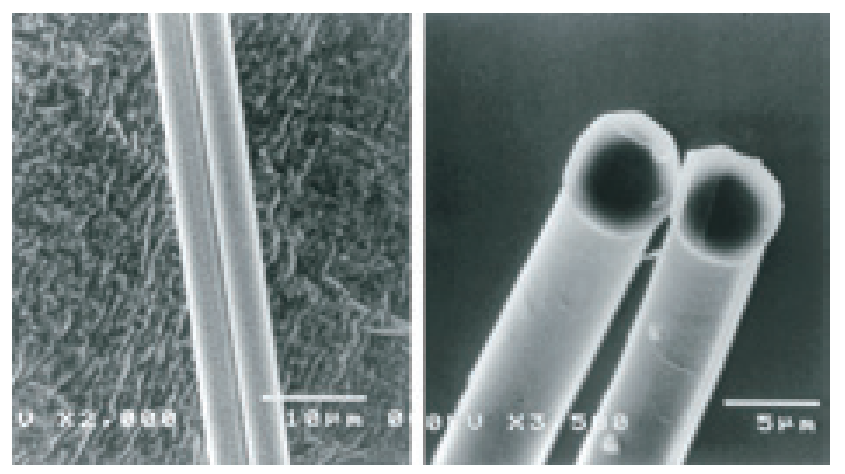

図 3 牽引糸の電子顕微鏡写真

二本のフィラメントからなる毫引糸

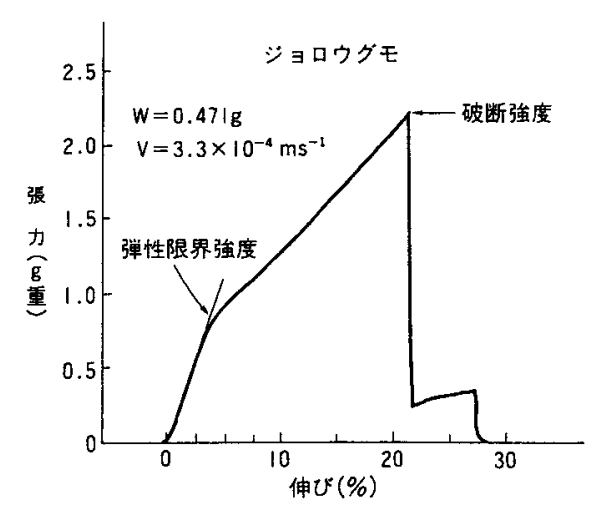

図 4 ジョロウグモ毫引糸の張力一伸び曲線 


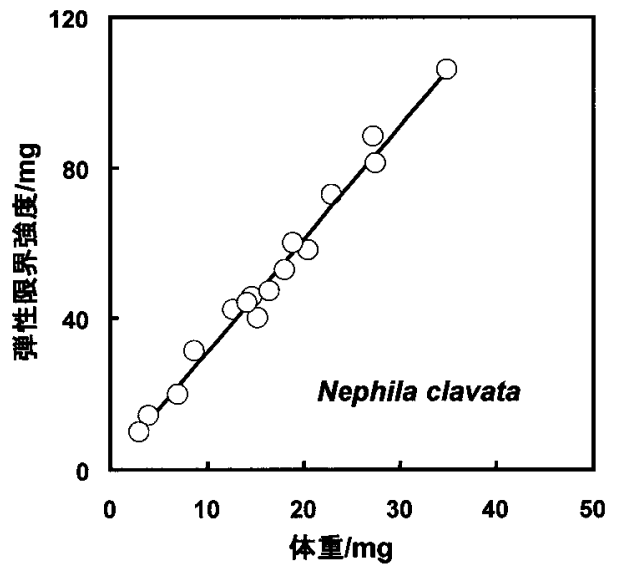

図 5 ジョロウグモの体重と牽引糸の弾性限界強度の関係

には最も効率的である。しかし、その唯一のフィラメント が切れてしまうとクモの命は保証されないので極めて危険 である。また、弾性限界強度がクモの体重の 2 倍であるよ うな太い一本のフィラメントから成る率引糸であっても安 全率は 2 となる。しかし、いくら太くても一本のフィラメ ントのどこかに亀裂が入るとすぐに切れてしまい、その結 果、クモは落下し命をなくしてしまうことになる。この点 からしても、牽引糸が二本のフィラメントからなっている ということは危機管理という観点から極めて重要な意味を 持ってくるのである。

二本のフィラメントのうち、いずれかの一本のフィラメ ントは危機時に必要な“ゆとり”として働くことになる。 それは命に対する“ゆとり”なのである。そのため、危機 管理という観点からみて、星引糸は最も効率的にクモの重 さを支えるシステムをとっていることになる。

安全性とエネルギーの観点から、最大の効率性とゆとり を持つ牽引糸によって初めて、クモの俊敏な活動性が保証 されていることになる。ここに、クモの命綱に関する“2” の安全則が得られたのである。

\section{3 危機管理の究極の数字は “2”}

“2”の安全則は、エレベーター、橋(図 6)、飛行機、家 屋、トンネルなどの構築物や紐などの工業用素材の安全率 や社会科学的な危機管理に対して、重要な示唆を与えてく れる1,13)。たとえば、家を造るとき、屋根を支える柱を太 くすると安全性は上がるが、費用がかかりすぎるとともに 使用できる空間が減ってしまう。また、家の柱を細くしす ぎると、屋根の重みで家がつぶれかねない。したがって、 構造物の素材に強度があって、なおかつ、適度な太さが必 要なのである。また、結婚式や卒業式などは、人生のうち で、TPO (時期、場所、機会)の点で二度と同じ状況にはめ ぐり合えないという記念すべきイベントである。そのよう な重要性から、万が一記念写真が映っていないという失態 を避けるために、一般にカメラのシャッターを最低 2 回は 切っている。

企業などでは、社長と会長などは同じ飛行機に乗って出 張しないことになっている。万が一事故が起こっても企業

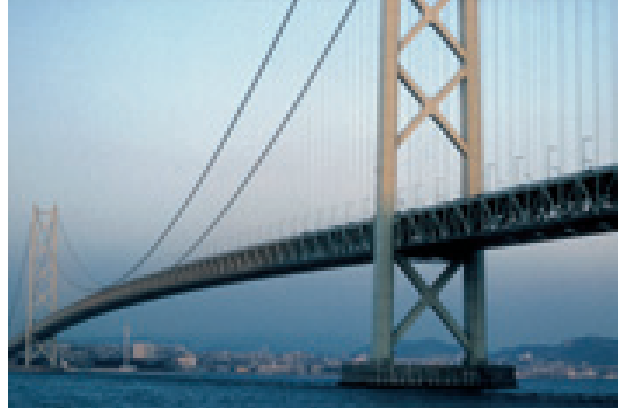

図 6 安全率が考慮されている明石海峡大橋

維持のために危険を分散している。また、重要なポストで は、出張の際に必ず代理をおいて危機管理に備えねばなら

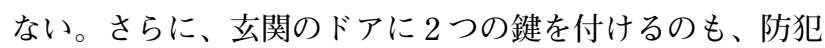
に対する危機管理なのである。

医療事故が起こる場合、しばしば油断して厳密なチェッ クを忘れている。最低二人が、それぞれ操作や処置を十分 に確認することにより、事故を避けることができるもので ある。いくら、一人が二倍の時間を費やしてチェックして も、安全性は本質的にはアップしない。ところが、問題点 を含む重要な書類が回覧されて、大勢の人が押印している にも拘らず、意外と簡単に関門を通過してしまうこともあ る。この場合、誰かがチェックしてくれるだろうと思い、 個別的には詳しくチェックしていないのである。多数で行 うことで、かえって責任の所在があいまいになるケースが ある。したがって、一人が十分にチェックした後、もう一 人が綿密にチェックする二人体制の方が効率的であると言 える。

\section{4 本当の “ゆとり”とは何か?}

クモの毫引糸は二本のフィラメントから構成されている が、その実態を調べてみると、クモの重さが二本のフィラ メントのそれぞれに分散している(図 7)。一本のフィラメ ントにはクモの半分の重量が加わっているに過ぎない。つ まり、クモは命綱の力学的機能の半分を危機管理用の“ゆ とり”として考えているのである。いくら“ゆとり”であっ

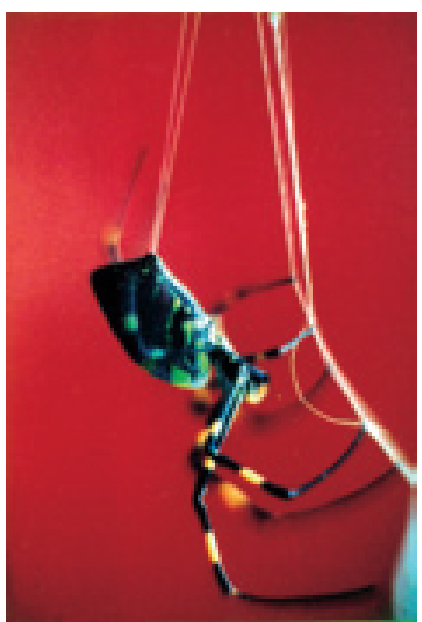

図 7 二本のフィラメントを出して獲物を待っているジョ ロウグモ 
ても、迅速さが要求される。たとえば、コンピューターは、 万が一故障をしても予備コンピューターを準備しておくこ とが大切である。いざという時に稼動しない場合もありえ るので、予備のコンピューターといえどもいつも稼動させ て、準備状態にしておくことは危機管理にとって非常に大 切なことである。

最近の “ゆとり教育”に扔いては、学習内容の軽減によ る学力低下が指摘されている。“ゆとり”とは、遊ぶこと を意味しているのではなく、いつでも役に立つための学習 を積み重ねておくことである。また、いくら学習しても、 いざという時に使えない知識だけでは、万が一の際に機能 する“ゆとり”にはなりえない。つまり、クモの命綱から 学ぶことは、本当の “ゆとり”とはいつでも機能しうる状 態にあることなのあろう。

\section{5 子グモは過保護でその安全率は“3”}

成体のジョロウグモの牽引糸で得られた安全率 “2”が 子グモに当てはまるのかどうかは興味深いことである。ク モの体重に対してプロットした弾性限界強度との関係で、 $50 \mathrm{mg}$ 以上の体重のジョロウグモでは、体重と弾性限界強 度のグラフでの傾きは間違いなくほぼ 2 であった。しかし、 体重が 50mg より小さい幼体のジョロウグモから採取した 牽引糸では、傾きがほぼ 3 であった。つまり、成体の安全 率は“約 2”であるが、幼体では“約 3”になる に年。子グ モでも毫引糸のフィラメントは 2 本であることから、子グ モの毫引糸の体重当たりの断面積が成体のクモより大きく 作られていることがわかった。多くの危険に曝されている 子グモは、遺伝的には過保護にされているのである。

\section{4. クモは紫外線を利用する！}

\section{1 クモの糸の紫外線劣化}

絹糸は紫外線によって劣化し黄变するため、絹素材の和 服を着て紫外線の強い屋外を歩くのは良くない。同じよう にタンパク質からなるクモの糸も紫外線で劣化することが 予想される。月ごとに採取したジョロウグモの㐮引糸に紫 外線を照射し、そのラジカル量を ESRで調べてみた(図 8)。 紫外線による化学結合の開裂によって、タンパク質分子の

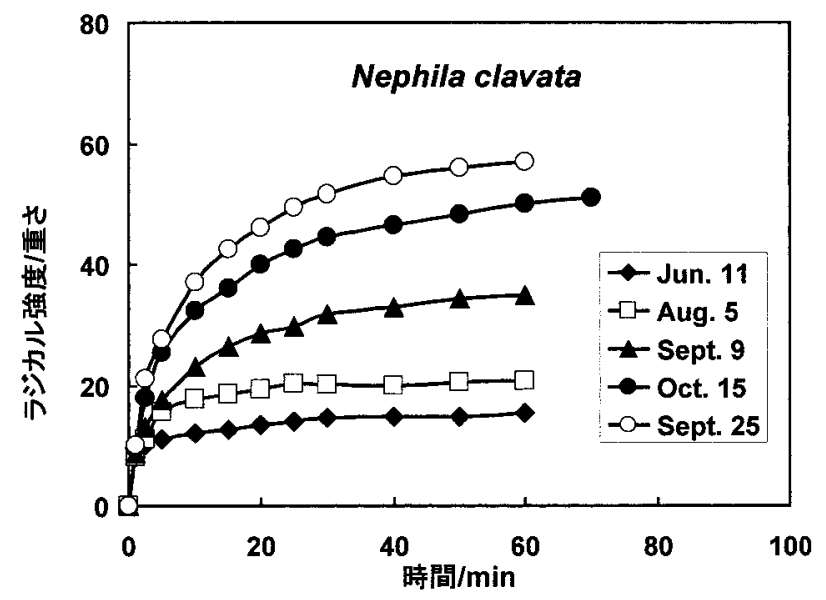

図 8 紫外線照射によるラジカル量の時間依存性
$\mathrm{C} \alpha$ 中心のラジカルが生成することが明らかになった。と ころが、若いクモの糸は成熟したクモよりラジカル量が少 なく、また、クモの糸の方が絹糸よりもラジカル量が少な い。このことは、絹糸よりクモの糸の方が、また、若いク モの糸ほど紫外線に対して劣化しにくいことを意味する15)。

\section{2 紫外線は巣を力学的に強くするのか?}

率引糸は力学的にクモの巣の骨格を構成する縦糸によく 似ている。その㲤引糸に太陽光の強度分布に似た紫外線 UV-A* (320-400 nm), UV-B* (290-320 nm), UV-C* (200-290nm)をそれぞれ照射した。率引糸の応力一ひずみ 曲線から求めた破断応力を紫外線照射時間に対して図示し た(図 9)。UV-C*照射の場合の応力は時間とともに大幅 に低下した。ところが、UV-B*照射の場合、応力が照射 直後に少し上昇してから低下した。また、UV-A*照射で は、応力は時間とともにかなり上昇し極大值を示してから 低下した ${ }^{18)}$ 。なお、ここで、応力は単位面積あたりの力学 強度を意味する。

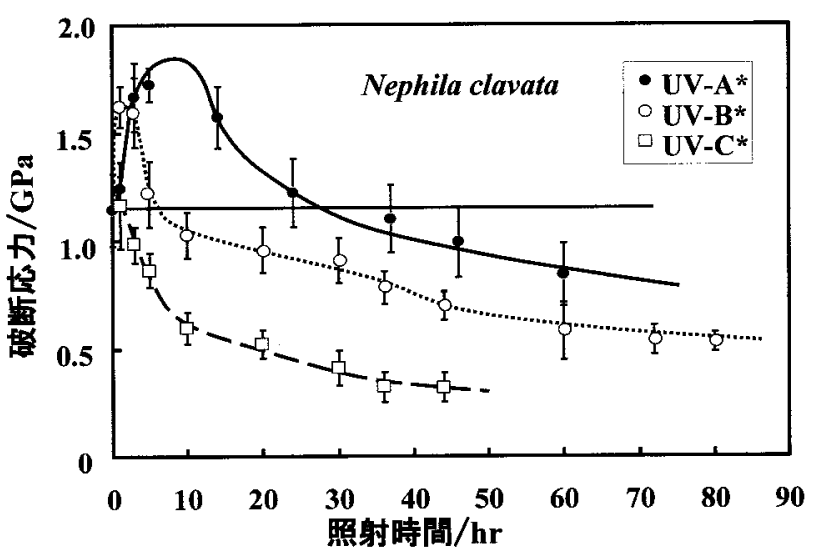

図 9 紫外線 $(\mathrm{UV}-\mathrm{A} *, \mathrm{UV}-\mathrm{B} *, \mathrm{UV}-\mathrm{C} *)$ 照射した後にお けるジョロウグモ毫引糸の破断応力の時間依存性

破断応力の極大值は、照射波長が大きくなると上昇した。 具体的には、破断応力の極大值は初期破断応力と比べて、

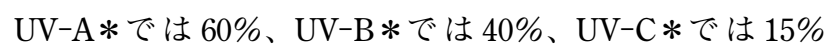
も増大した ${ }^{18)}$ 。この結果から、紫外線照射によって、クモ の糸を構成するタンパク質が分解して分子量が低下して力 学強度が低下する因子と、架橋によって分子量が増加して 力学強度が上昇する因子の二つの因子の重ねあわせによっ て、破断応力が極大を示すものと思われる。特に、UV-A* の紫外線が架橋の生成に大いに寄与していることがわかる。

紫外線照射によって、極大值になるまでの時間は波長が 長くなるほど長くなる。この極大值になるまでの時間は、 破断強度が初期值よりも大きい期間に比例した。太陽光か ら UV-A と一部の UV-B が地上に降り注いでいる。UV-A *照射に関して一日の太陽光の照射時間を換算したところ、 力学応力が初期值にまで低下する時間は、ジョロウグモが 巣を張り替える周期(二日間) とよく対応した。つまり、ジョ ロウグモの巣は糸の破断応力が一定の值に低下すると、巣 を張りかえるのであろう。このように、ジョロウグモは紫 
外線を上手に利用していることがわかった。

\section{5. クモの糸から学ぶ信頼性}

\section{1 クモの糸の線形領域は変化しにくい}

ジョロウグモは巣を構成する糸の力学強度の限界值をよ く理解していることが分かってきた。ところで、クモは自 らの命を託する命綱をどこまで信頼しているのであろう か? 興味深い問題である。

晴れや最りなどの天気の具合によって地上に降りそそぐ 紫外線量が異なる。そのため、紫外線によって糸の破断応 力も大幅に変わりえることが予想される。このようなこと から、糸の破断応力に打ける非線形挙動をクモが正確に予 測することは、事実上極めて難しいと考えられる。

牽引糸に UV-Aより分解力の強い UV-B を照射すると、 率引糸の破断応力が大幅に減少する。しかし、牽引糸の弾 性限界応力は、長時間にわたりほとんど変化しないことが わかった(図 10) ${ }^{19)}$ 。つまり、弾性限界応力は、紫外線を 長時間照射しても変化しないように設計されている。この ように、クモは毫引糸の力学特性の線形領域には絶対的な 信頼性を打くことができる。つまり、クモにとっては線形 領域だけは間違いなく予測可能な領域なのだ。

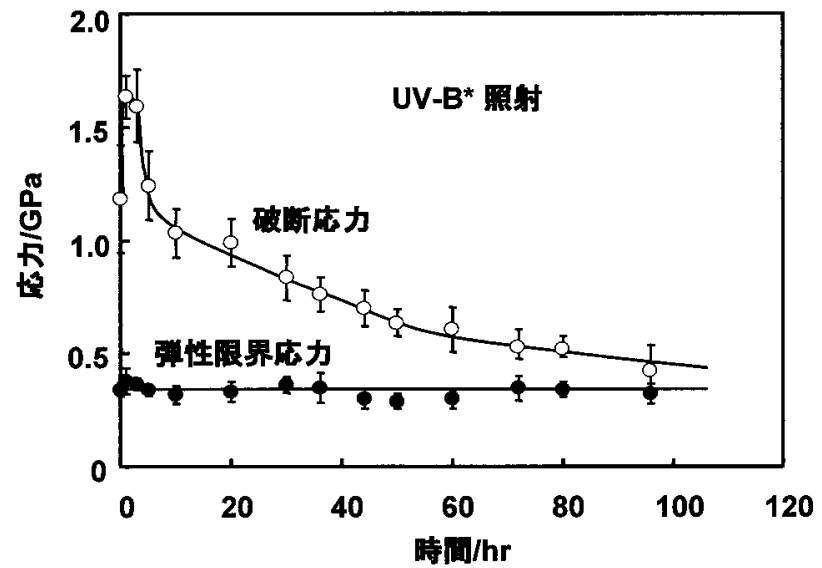

図 10 ジョロウグモ毫引糸の弾性限界応力および弾性限界 応力の紫外線 $(\mathrm{UV}-\mathrm{B} *)$ 照射時間依存性

\section{2 クモは命綱のどこを信じるのか?}

同じクモから採取した牽引糸から複数個のサンプルを作 り、そのサンプルの張力一伸び曲線を測定すると、バネの ように伸び縮みができる線形領域ではデータの再現性は非 常に良い。そのため、原点から弾性限界点までは、どれく らいの力を加えるといくら伸びるのかを十分予測すること ができる。その結果、牽引糸に対する信頼感が生まれてく る。たとえば、体重計のバネは使用可能な範囲では体重と 目盛りの間に線形(比例)関係が成立している。そのため、 我々は体重計の線形部分のみを信用しているのである。し かし、バネの弾性限界強度以上に重い人が体重計に乗って バネが非線形的に変形してしまうと、体重計は正常に機能 しなくなる。

また、牽引糸にクモがぶら下がっても弾性限界伸びの半 分の長さまでしか伸びないので、クモが命を落とすことは
まずありえない。牽引糸は弾性限界点以下では正常なバネ として機能するので、線形領域では確実にクモの安全性が 保証されているのである。

率引糸の破断強度はクモの体重の約 6 10 倍であるので、 牽引糸に弾性限界点以上の力が加わっても毫引糸はすぐに は切れないはずである。しかし、弾性限界点以上の張力を 加えると、伸びはサンプル毎に測定值は大きく変わるなど して、データの再現性は悪く、糸が切れる可能性は十分あ る。したがって、牽引糸に弾性限界点以上の力が加わった 非線形領域では、クモは牵引糸にぶら下がり続けても 100 \%安心するわけにはいかない。つまり、クモには牽引糸が いつ切れるかもしれないという不安が常につきまとう。こ のようなことから、クモは牽引糸の力学的線形領域の限界 点までしか信頼がおけないことを十分に承知していると考 えざるを得ない。

要するに、安全性の観点からクモが命を託せるのは線形 領域の挙動に対してのみということになる。クモは糸の弾 性限界強度を安全性の基準值として採用し、線形領域の限 界内に自らの命を委託して行動していると考えるのは、妥 当と思われる。このことは、クモは予測が可能な命綱の線 形領域に絶対的な信頼をおいていることに他ならないので ある ${ }^{19)}$ 。

\section{3 信頼できる相手は線形関係が成立する！}

クモは線形領域を信頼できるようだが、はたして人間の 場合はどうであろうか? 人間が信頼できる相手となるかど うかは、クモと同じように、刺激(指示) と応答(報告)が線 形的か、非線形的かによって、決まることがわかった。

多くの組織において、上司というものは、安心して仕事 をまかせられる部下を心に決めている。ところが、そんな 部下ほど忙しいもので、ときに、暇な部下に仕事を与えて みると、期日が過ぎてもまともな報告をしてこないことが 多い。

上司から見た信頼できる部下とは、上司が指示(刺激)し た課題に対して期限内に予想通りに報告(応答)してくれる など、指示と報告との間に線形関係が成立する人物である (図 11) ${ }^{19)}$ 。両者の間に線形が成立すれば、上司にとって はさらなる課題を課してもあらかじめ部下の報告が予測で きるので、全体の仕事を遂行しやすい。そのため、線形の 成立する部下は上司から見れば信頼に值する。一方、指示 とまるっきり違ったデタラメな報告しかできない部下は、 上司の指示と部下の報告との間に線形関係は成立しない。 このような部下は、当然のことながら上司にとっては信頼 が打けないのである。

このような信頼性は様々なケースに当てはめられる。た とえば、数週間先の短期的未来は現在の生活の延長で線形 的に話が進むことが多いから、信頼しやすい。ところが、 中長期的未来は非線形的に推移するため、予測することは 極めて難しい。そのため、中長期的な話は夢の話で終わる ことが多いために信頼できないのである。 


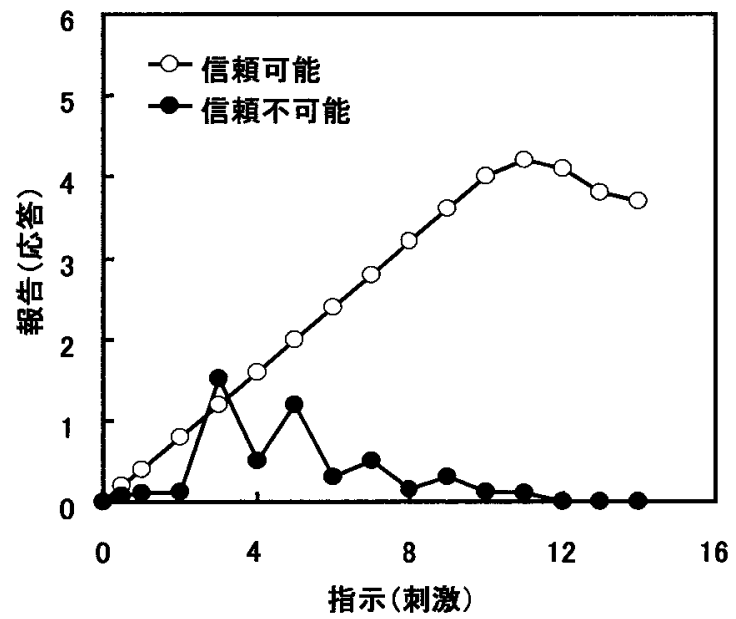

図 11 信頼できる部下と信頼できない部下のパターン比較 上司の指示 (刺激) と部下の報告 (応答) との間に直線 関係が成立する領域に信頼関係が成立する。しかし、 上司との間に直線関係の成立しない部下は信頼され ない。○：信頼できる部下 ○：信頼の置けない部 下

\section{6. おわりに}

クモの秘密を探るべく、クモの牽引糸の性質を調べてみ たところ、非晶性で柔軟性があり、弾性率が高く、耐熱性 にすぐれた素材であることが判ってきた。その特徴ある牽 引糸の秘密を䙼いてみると、4 億年という長い進化の歴史 の間に、“安全” と “信頼” の原点が秘められていること がわかってきた。

空中で死と直面しているクモが俊敏に行動できるのは、 二本のフィラメントからなる牽引糸を安心して信頼できる 最も効率的なシステムを作り上げていることに起因してい る。また、重要なことは、クモが牽引糸に命を預ける際に、 確実に信頼できるのは、あくまでも張力一伸び曲線におけ る線形領域なのである。率引糸の力学的な非線形領域では フィラメントが切れる可能性があるため、クモは非線形領 域を信頼できないのである。このように、クモの牽引系の 弾性限界点までの線形領域は安全性と信頼性の原点として 極めて重要な役割を担っている。4 億年の長い進化の歴史 の間に、死と直面してきたクモが生き延びてきた原点がわ かったように思われる。

自然環境の中で生活している人間は、古くから予測不可 能で解釈できない多くの事象に遭遇してきた。それらを少 しずつ克服しながら、人類は 20 世紀に高度な技術を発展 させた。しかし、いくらハイテクノロジーといえども、今 後多くの困難な問題が次々と待ち受けており、人類が単純 にそれらの問題を乗り越えることは極めて難しい。このよ うな状況では、神秘的で歴史のある自然界から様々な情報 を得ることが不可欠になってくる。まさに、21 世紀の科 学技術の展開には、このような自然界からヒントを得るこ とがますます重要になってくると思われる。

なお、クモの糸は柔軟性があり、弾性率もかなり高く、 エネルギーを吸収する効果があるため、防弾チョッキの素 材としてふさわしいと考えられている。また、ストッキン
グや医療用の縫合糸への応用も期待されている。クモの遺 伝子組み換えによってクモの糸を作ったことが報告され20)、 それをきっかけに世界的に遺伝子工学によるクモ糸の大量 生産への期待が高まっている。ただ、これらの紡糸過程に 多くの課題が残っている ${ }^{21)}$ 。一方、生産の経済的な観点か ら、クモの糸の特徵的な構造と微細構造を持つ人造タンパ ク質繊維を作る研究が検討され始めた ${ }^{22,23)}$ 。

\section{参考文献}

1）大嵪茂芳、“クモの糸のミステリー”中公新書，東京 (2000).

2) S. Osaki, Acta Arachnologica, 37, 69 (1989).

3) S. Osaki, Acta Arachnologica, 38, 21 (1989).

4) S. Osaki and K. Yamamoto, unpublished data.

5) S. Osaki, 化学の領域, 36, 62(1982).

6) S. Osaki, Nature, 347, $132(1990)$.

7) S. Osaki, "Macromolecular Nanostructured Materials", KODANSHA Springer, London, p.297 (2004).

8) J. M. Gosline, M. W. Denny and M. E. DeMont, Nature, 309, 551(1984).

9) P. M. Cunniff, S. A. Fossey, M. A. Auerbach and J. W. Song, "Silk Polymers", Amer. Chem. Soc., Washington, D. C., p234 (1995).

10) A. M. Becker, D. V. Mahoney, P. G. Lenhert, R. K. Eby, D. Kapln and W. W. Adams, "Silk Polymers", American Chemical Society, Washington, D. C., p.185(1995).

11) S. Osaki and R. Ishikawa, Polym. J., 34, 25(2002).

12) K. Nakamae, T. Nishino, K. Hata and T. Matsumoto, Kobunshi Ronbunshu, 42, 211(1985).

13) S. Osaki, Nature, 384, 419(1996).

14) S. Osaki, Int. J. Bio.Macro., 24, 283 (1999).

15) S. Osaki, Polym.J., 35, 261 (2003).

16) S. Osaki, K. Yamamoto, A. Kajiwara and M. Murata, Polym. J., 36, 3 (2004).

17) S. Osaki, Polymerwerkstoffe 2002, Halle, Germany, 617 (2002).

18) S. Osaki, Polym. J., 36, 657 (2004).

19）大㠃茂芳, “クモはなぜ糸から落ちないのか”, PHP 新書, 東京 $(2004)$.

20) C. A. Lazaris, S. Arcidiacono, Y. Huang, J. F. Zhou, F. Duguay, N. Chretien, E. A. Welsh, J. W. Soares and C. N. Karatzas, Science, 295, 472(2002).

21) C. Dicko, J. M. Kenny, D. Knight, F. Vollrath, Biochem, 43, 14080 (2004).

22) J. O'Brien, S. Fahnestock, Y. Termonia, K. Gardner, Adv. Mater., 10, 1185(1998).

23) T. Scheibel, R. Parthasarathy, G. Sawicki, X-M. Lin, H. Jaeger, S. Lindquist, Natl. Acad. Sci. USA, 100, 4527 (2003). 